https://doi.org/10.11646/zootaxa.4244.4.9

http://zoobank.org/urn:lsid:zoobank.org:pub:27252617-2E42-4AF0-B054-3C13BA8BC5A1

\title{
Honouring His Royal Highness the Crown Prince of Bhutan: Megalestes gyalsey (Odonata: Synlestidae)
}

\author{
T. GYELTSHEN ${ }^{1}$, V.J. KALKMAN ${ }^{2} \&$ A.G. ORR ${ }^{3}$ \\ ${ }^{1}$ School of Life Sciences, Sherubtse College, Kanglung, Bhutan.E-mail: thinleytshen@gmail.com \\ ${ }^{2}$ Naturalis Biodiversity Center, P.O. Box 9517,2300 RA Leiden, The Netherlands.E-mail: vincent.kalkman@naturalis.nl \\ ${ }^{3}$ Environmental Futures Research Institute, Griffith University, Nathan, Queensland 4111, Australia. E-mail: agorr@bigpond.com
}

\begin{abstract}
Megalestes gyalsey spec. nov. is described from a single male from Trongsa District in Bhutan. The species was discovered during field work conducted in 2015 for the Bhutan invertebrate biodiversity project. The species is named in honour of His Royal Highness Crown Prince Jigme Namgyel Wangchuck, the Gyalsey of Bhutan, on the occasion of his first birthday.
\end{abstract}

Key words: Damselfly, Zygoptera, Bhutan, Himalaya

\section{Introduction}

The Bhutanese monsoon of summer 2016 was unusually fierce, with flash floods sweeping away houses, roads and bridges. Water is not only a source of life but can also bring destruction. The increase in the intensity of the monsoon in the last few years might be caused by climate change, which is neither caused by Bhutan nor can be halted by Bhutan. The country can, however, take precautions to reduce the impact of flash floods by protecting water courses and restoring vegetation bordering rivers and streams. As a result of the government's policy of protecting the landscape and forest, the natural vegetation along most water courses found in Bhutan is intact. Nonetheless there are some streams where the natural vegetation is under human pressure. Since 2015 the authors of this paper have been co-operating to map the distribution of the dragonflies and damselflies of Bhutan as part of the Bhutan invertebrate biodiversity project. Many odonate species depend for their habitat on brooks and streams with largely undisturbed vegetation and disappear when the vegetation becomes degraded. It is our hope that by mapping the distribution of dragonflies and damselflies we can pinpoint areas in need of protection and use the presence of these beautiful and charming insects to communicate to Bhutanese people the need to protect the integrity of streams and rivers.

During fieldwork in 2015 we encountered a large damselfly which is new to science (Fig. 1). We are deeply honoured to have received permission to name this species after His Royal Highness the Crown Prince of Bhutan, the Gyalsey, Jigme Namgyel Wangchuck on the occasion of his first birthday.

The genus Megalestes belongs to the Synlestidae, a family currently comprising nine genera and 36 species. The phylogenetic relationship between Synlestidae and the American family Perilestidae is still unclear (Dijkstra et al. 2013), and further molecular analysis might indicate that these two should be combined. The species of Synlestidae as currently defined occur in eastern Australia (Chorismagrion, Episynlestes, Synlestes), southern Africa (Chlorolestes, Ecchlorolestes), western Africa (Nubiolestes, Cameroon and Nigeria), Hispaniola in the Caribbean (Phylolestes) and mainland Asia (Megalestes, Sinolestes) (Fig. 1). This distribution pattern is believed to reflect the Gondwanan history of the family, suggesting that the family is over 100 million years old. Two genera, Megalestes and Sinolestes, occur in mainland Asia. Sinolestes editus, the sole species of its genus, is restricted to mainland southern China (Guangxi, Guangdong, Guangzhou, Fujian and Zhejiang) and Taiwan and is found between 500 and $1500 \mathrm{~m}$ (Wilson 2009). The genus Megalestes currently includes 17 species. All of these are 
relatively large, mainly metallic green or greenish damselflies with a yellow pattern on the thorax (mainly on the sides) and, in males, often pruinose markings at the tip of the abdomen. Their size, metallic colours and their habit of resting with the wings outspread and the abdomen held vertical, makes it easy to recognize them in the field. The species of Megalestes are found throughout a large part of the wet subtropical regions of mainland Asia including Taiwan, China and the northern parts of Vietnam, Thailand, Myanmar and India and Bhutan and Nepal. They are restricted to mountainous areas with marked seasonal variations in temperature and the adults are thus also seasonal in their phenology. The species of Megalestes are, like all other species of Synlestidae, restricted to small streams or puddles or pools associated with streams. Most species frequent steep, often rocky mountain brooks. The highest diversity is found in southern China (Table 1). The Indian subcontinent is home to six species. Of these M. major (Selys, 1862) is the most common, being widespread and common throughout large parts of the Himalayas in Nepal, India and Bhutan. Megalestes irma Fraser, 1926, occurs in the same area but seems less common. Megalestes micans Needhan, 1930, M. kurahashii Asahina, 1985, and M. lieftincki Lahiri, 1979, are found in the Himalayas in northeastern India (Arunachal Pradesh) but have not been found in Bhutan or to the west of it. The sixth species, Megalestes raychoudhurii Lahiri, 1987, is restricted to the Khasi Hills in Meghalaya, south of the main range of the Himalayas. During fieldwork in Bhutan in 2015 and 2016 we encountered three different species of Megalestes: M. major, M. irma and a third species, which is new to science and is described in this paper.

TABLE 1. Distribution of genera Megalestes and Sinolestes, the Asian members of the family Synlestidae. Megalestes suensoni Asahina, 1956, is considered a synonym of Megalestes heros Needham, 1930. Information on distribution is based on the following references: Myanmar: Lieftinck 1948; China (mainland): Chao 1965, Wilson \& Reels 2003, Wilson \& Xu 2007, Zhou \& Zhou 2008; India: Fraser 1933, Lahiri 1979, Lahiri 1987, Asahina 1985, Wilson \& Xu 2007; Taiwan: Yeh et al. 2006; Nepal: Vick 1989; Thailand: Hämäläinen \& Pinratana 1999, Asahina 1985; Vietnam: Asahina 1997; Karube 2014; Do \& Dang 2007.

\begin{tabular}{|c|c|c|c|c|c|c|c|c|}
\hline & Bhutan & Myanmar & $\begin{array}{l}\text { China } \\
\text { (mainland) }\end{array}$ & India & Nepal & Taiwan & Thailand & Vietnam \\
\hline \multicolumn{9}{|l|}{ Megalestes } \\
\hline Megalestes australis Karube, 2014 & & & & & & & & $\mathrm{x}$ \\
\hline Megalestes chengi Chao, 1947 & & & $\mathrm{x}$ & & & & & \\
\hline Megalestes discus Wilson, 2004 & & & $\mathrm{x}$ & & & & & \\
\hline Megalestes distans Needham, 1930 & & & $\mathrm{x}$ & & & & & $\mathrm{x}$ \\
\hline Megalestes gyalsey sp. nov. & $\mathrm{x}$ & & & & & & & \\
\hline Megalestes haui Wilson \& Reels, 2003 & & & $\mathrm{x}$ & & & & & $\mathrm{x}$ \\
\hline Megalestes heros Needham, 1930 & & & $\mathrm{x}$ & & & & & \\
\hline Megalestes irma Fraser, 1926 & $\mathrm{x}$ & & & $\mathrm{x}$ & $\mathrm{x}$ & & & \\
\hline Megalestes kurahashii Asahina, 1985 & & & & $\mathrm{x}$ & & & $\mathrm{x}$ & \\
\hline Megalestes lieftincki Lahiri, 1979 & & & & $\mathrm{x}$ & & & & \\
\hline Megalestes maai Chen, 1947 & & & $\mathrm{x}$ & & & $\mathrm{x}$ & & \\
\hline Megalestes major Selys, 1862 & $\mathrm{x}$ & $\mathrm{x}$ & & $\mathrm{x}$ & $\mathrm{x}$ & & & \\
\hline Megalestes micans Needham, 1930 & & & $\mathrm{x}$ & $\mathrm{x}$ & & & & $\mathrm{x}$ \\
\hline Megalestes omeiensis Chao, 1965 & & & $\mathrm{x}$ & & & & & \\
\hline Megalestes palaceus Zhou \& Zhou, 2008 & & & $\mathrm{x}$ & & & & & \\
\hline Megalestes raychoudhurii Lahiri, 1987 & & & & $\mathrm{x}$ & & & & \\
\hline Megalestes riccii Navás, 1935 & & & $\mathrm{x}$ & & & & & \\
\hline Megalestes tuska Wilson \& Reels, 2003 & & & $\mathrm{x}$ & & & & & \\
\hline \multicolumn{9}{|l|}{ Sinolestes } \\
\hline Sinolestes editus Needham, 1930 & & & $\mathrm{x}$ & & & $\mathrm{x}$ & & \\
\hline
\end{tabular}




\section{Methods}

Descriptive terminology largely follows Watson \& O'Farrell (1991). The following abbreviations are used: Fw: Forewing; Hw: hindwing; Ax: antenodal crossveins; Px: postnodal crossveins. The abbreviation S1-10 indicates abdominal segments 1 to 10 . RMNH refers to the Naturalis Biodiversity Center (formerly Rijksmuseum van Natuurlijke Historie), Leiden, The Netherlands.

\section{Megalestes gyalsey sp. nov.}

(Figs 1-4)

Material examined. Holotype $\widehat{\jmath}$. Bhutan, Trongsa District, along Wangdue - Trongsa Highway, (27.457N, 90.368E; $2450 \mathrm{~m}$ a.s.1.), 17.x.2015, leg. T. Gyeltshen \& V.J. Kalkman. The type is stored at the collection of the National Biodiversity Centre, Bhutan (NBCB-00252). DNA material is stored at the collection of the RMNH (RMNH.5015087). The species was present at a small brook running through deciduous forest and was caught at a small open area where the brook reached the road verge (Fig. 2).

Etymology. The specific epithet gyalsey, is a noun in apposition. The species is named in honour of His Royal Highness Crown Prince of Bhutan, The Gyalsey, Jigme Namgyel Wangchuck, on the occasion of his first birthday.

Description of holotype male. Head: Labium pale yellow. Head shining metallic coppery green with pale yellow markings on anterior corners of labrum, mandibles except upper anterior corner, and genae directly adjacent to mandibles. Antennae black, ocelli pale. Posterior part of head, behind ocelli, matt greyish black.

Thorax: Pronotum with central two-thirds of both anterior and posterior lobe yellow, remainder metallic greenish to black. Posterior lobe normally developed, lacking specialised processes or excavations. Side of prothorax metallic greenish to black with lower margin adjacent to coxa a U-shaped yellow area. Synthorax intense metallic green on dorsum and sides, covering entire mesepimeron and most of mesinfraepisternum apart from a small yellow mark at posteroventral corner. Metepisternum and metepimeron largely yellow but with broad metallic green band along suture reaching to half breadth of spiracle and continued as dull black in most of anterior part of metainfraepisternum (Fig. 3). Coxae and trochanters of first two pairs of legs largely yellow, coxae and trochanters of third pair of legs yellow with large black patch as shown in Fig. 3. Remainder of legs black.

Wings: Membrane tinted light brownish amber, venation dark brown to black; pterostigma dark brown to black, narrow, elongate and slightly expanded in middle, extending over 3-4 cells. Wing base petiolated to about halfway between Ax1 and Ax2. Right Fw has 3 Ax, all other wings have 2 Ax. Px 18 in the Fw; 15-17 in Hw.

Abdomen:Largely dark with slight metallic green sheen, darker posteriorly; S1 and especially S2 bright metallic green dorsally and laterally. Ventral half of side of S1 and ventral third of S2 pale yellow. Dorsum of segments 9-10 pale pruinose blue. Anal appendages black and shaped as in Fig 4a-b. Cerci longer than S10, basally broad with a short, blunt, posteriorly directed finger-like process on the interior, remainder of interior margin smooth and lacking spines. In lateral view apical third bent downward and apex bifurcated with rounded upper process and slightly longer narrow acute lower process. Paraprocts a little over half as long as cerci, each with broad base, especially distinctive in lateral view, narrowing halfway and with apical half forming a strong, narrow, apically pointed finger-like process; tips slightly divergent in dorsal view.

Measurements (mm): total length 58; abdomen 47.5, Fw 36; Hw 35.

Female Unknown.

Differential diagnosis. Megalestes and Sinolestes are the only damselfly genera in mainland Asia with a pterostigma that is at least twice as long as broad, a metallic green colouration and a total length of over $50 \mathrm{~mm}$. The only genus matching the first two characters is Lestes, but the species of that genus are smaller and have R4 and Ir3 originating well proximal of the subnodus (at the subnodus in Megalestes and Sinolestes). Megalestes gyalsey can best separated from all other species of Megalestes and Sinolestes based on its anal appendages: the paraprocts are slightly over half the length of the cerci and have a relatively simple structure with the apical half consisting of a strong apically pointed gently curved finger-like process and lacking small upcurved spines. Figure $4 \mathrm{c}-\mathrm{f}$ shows the anal appendages of Megalestes major and M. irma, the two other species of the genus known from Bhutan. 


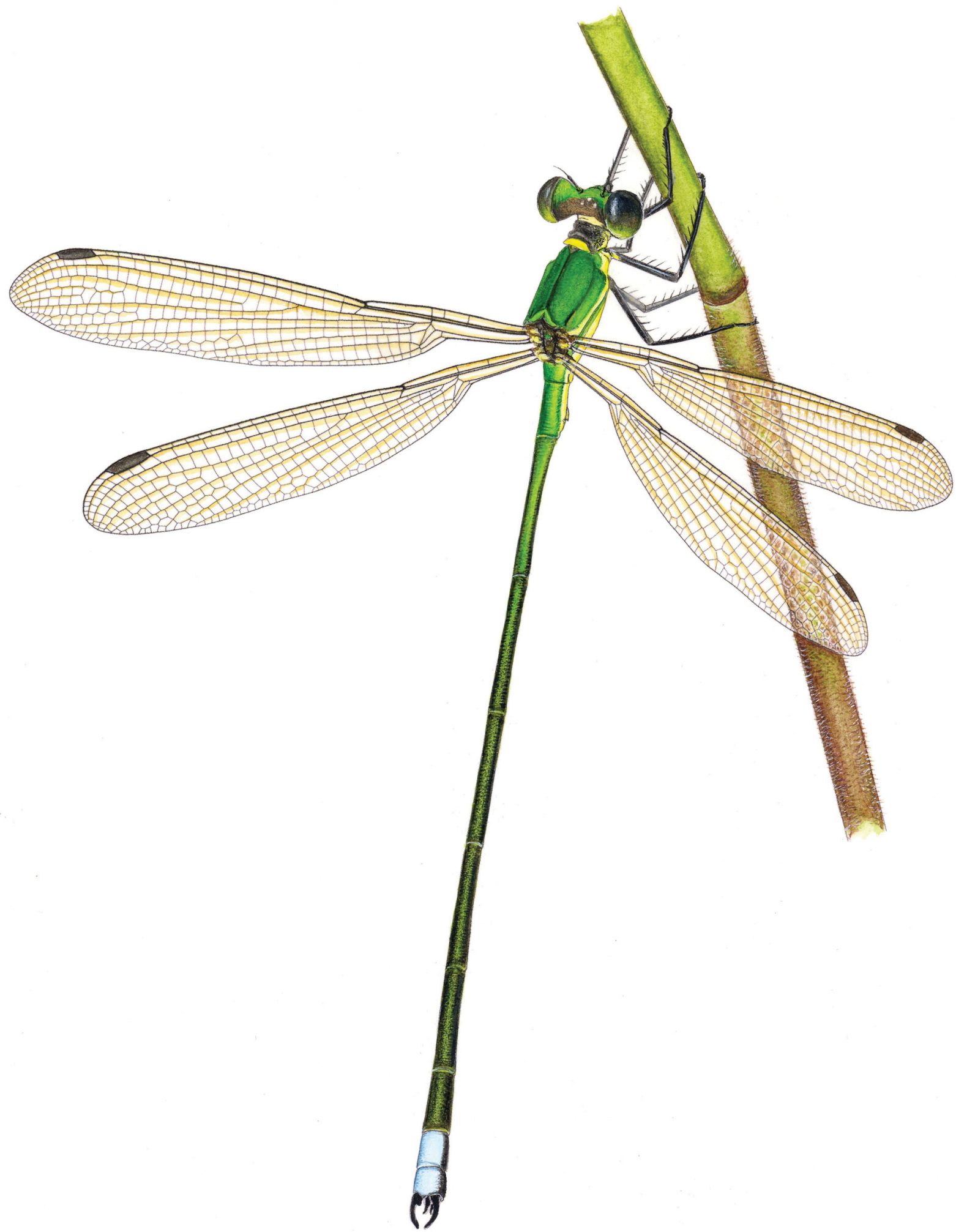

FIGURE 1. Megalestes gyalsey represented in life (watercolour drawing by Albert Orr). 


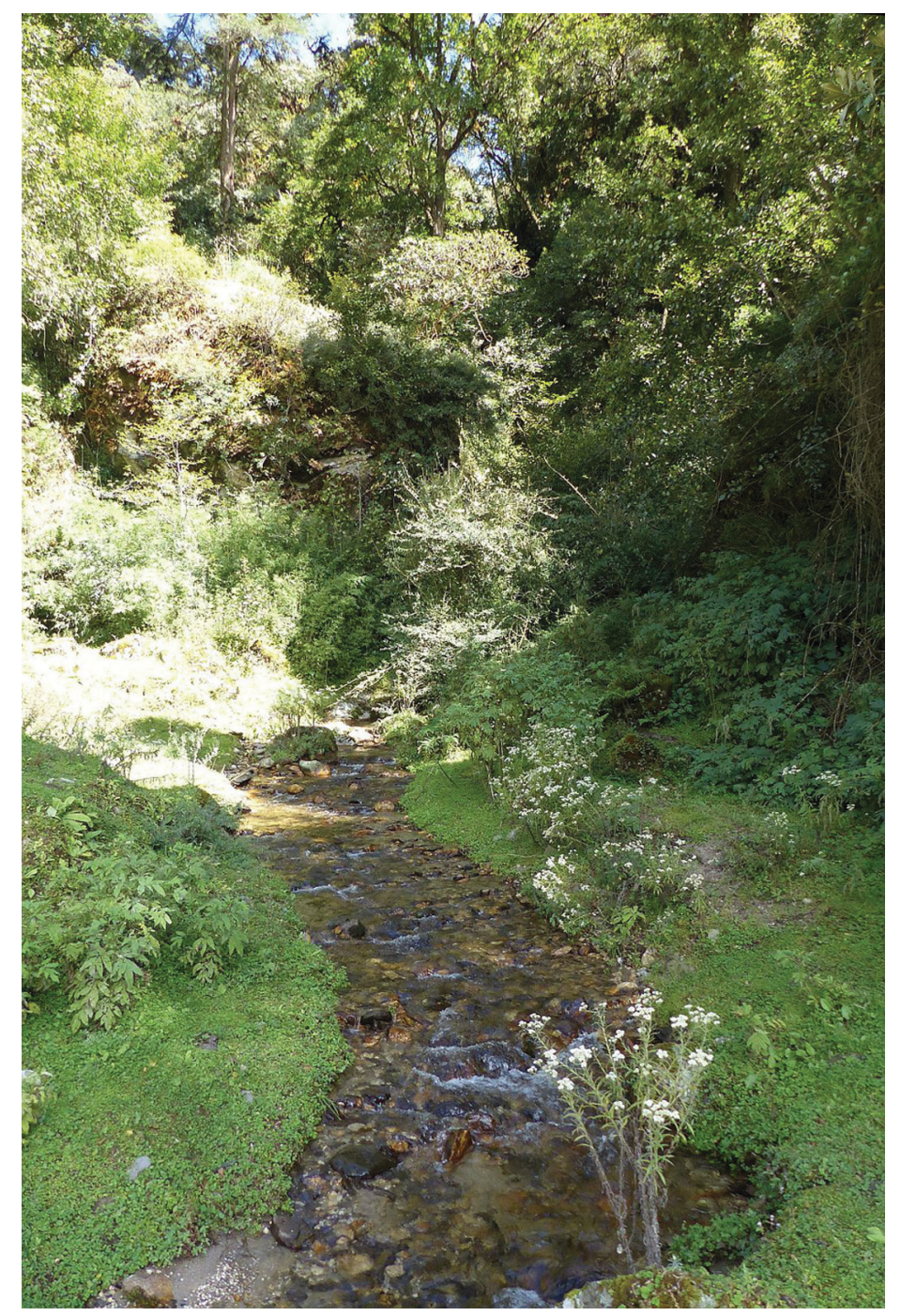

FIGURE 2. Habitat of Megalestes gyalsey.

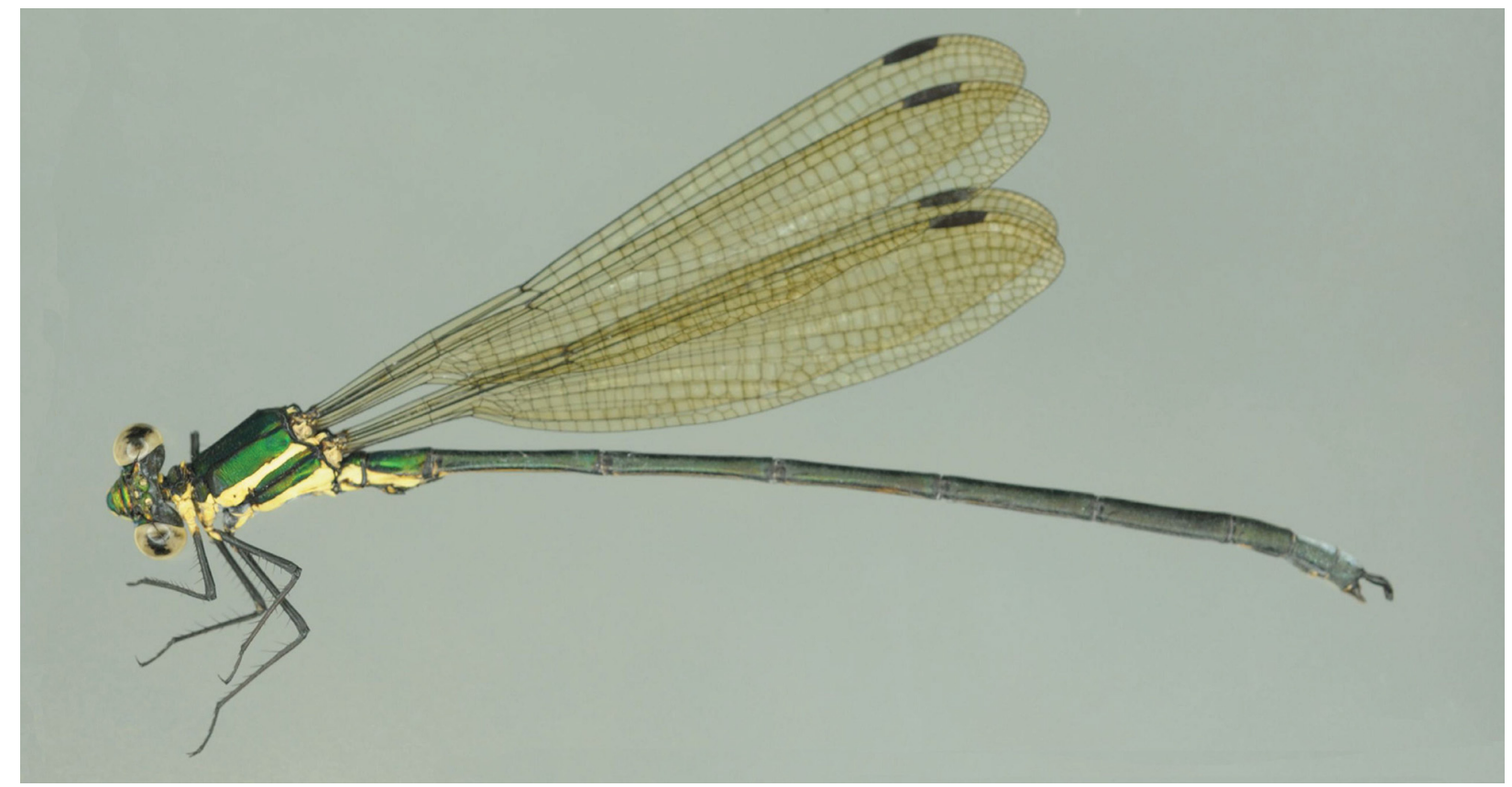

FIGURE 3. Holotype of Megalestes gyalsey. 


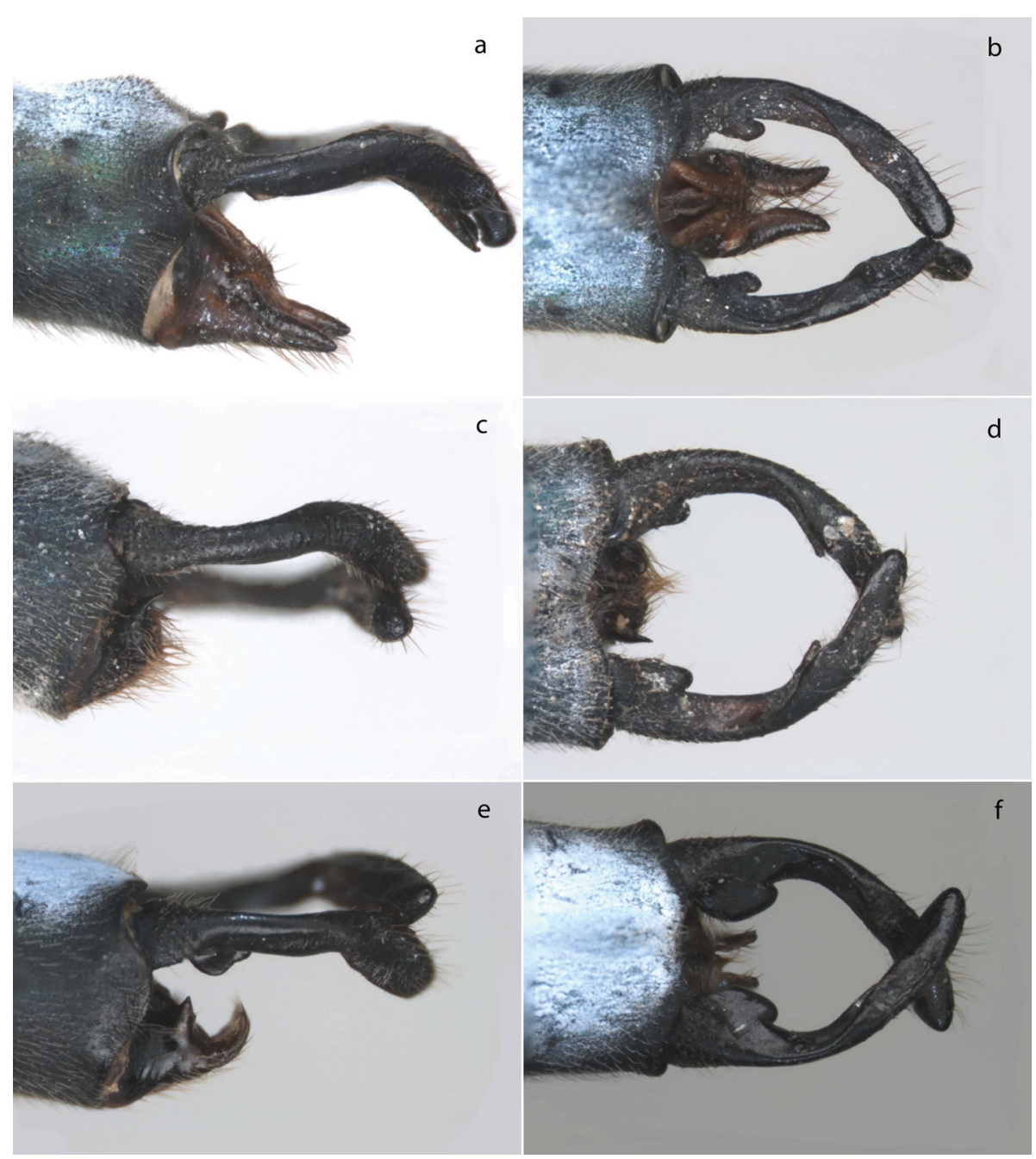

FIGURE 4. Anal appendages of the three species of Megalestes recorded from Bhutan: Megalestes gyalsey (holotype) (a) lateral view, (b) dorsal view; Megalestes major (c) lateral view, (d) dorsal view; Megalestes irma (e) lateral view, (f) dorsal view.

\section{Discussion}

Megalestes gyalsey is the eighteenth species of Megalestes. It is currently known only from the type locality in Bhutan but is likely to occur in adjacent areas of India and might be found in the eastern parts of Nepal. Further field work might result in the discovery of more species of Megalestes, especially in parts of China, but new species might yet be found in the Himalayan region as well. There is little information on the habitat and life history of Megalestes gyalsey or any other species of the genus Megalestes and it would be interesting to study the behaviour and seasonality of the species. Although only one location is known for the species, there is no reason to assume that it is threatened, as much probably suitable habitat is present in Bhutan. Nonetheless, it would be desirable to further explore the region in order to locate more populations.

\section{Acknowledgements}

The authors are grateful to the Bhutan Trust Fund for Environmental Conservation (BTFEC) for funding this study and the National Biodiversity Centre (Bhutan) for supporting the field survey work. We are also grateful for the support we received from Sangay Dema (National Biodiversity Centre, Bhutan) during the organization of the project. 


\section{References}

Asahina, S. (1985) Contributions to the taxonomic knowledge of the Megalestes species of continental South Asia (Odonata, Synlestidae). Chô Chô, 8 (10), 1-17.

Asahina, S. (1997) Records of the northern Vietnamese Odonata taken by the expedition members from the National Science Museum, Tokyo. 6. Platystictidae, Megapodagrionidae, Lestidae and Synlestidae. Bulletin of the National Science Museum, Series A, 23, 107-113.

Chao, H.-F. (1965) A study of the Chinese dragonflies of the genus Megalestes Selys, with description of new species (Odonata: Synlestidae). Acta Zootaxonomica Sinica, 2 (3), 187-196. [in Chinese with English summary]

Do, M.C. \& Dang, T.T.H. (2007) Checklist of Dragonfly from Vietnam. Vietnamese National University Publisher, Hanoi, $6+$ $181 \mathrm{pp}$.

Fraser, F.C. (1933) The Fauna of British India, including Ceylon and Burma. Odonata. Vol. I. Taylor \& Francis, London, 423 pp.

Hämäläinen, M. \& Pinratana, A. (1999) Atlas of the dragonflies of Thailand. Distribution maps by provinces. Brothers of St. Gabriel in Thailand, Bangkok, 176 pp.

Karube, H. (2014) Vietnamese Odonata collected in 1992-2003 surveys. IV. Synlestidae. Tombo, 56, 73-76.

Lahiri, A.R. (1979) Odonata (Insecta) from different states of north eastern India. Oriental Insects, 13 (1/2), 119-132. https://doi.org/10.1080/00305316.1979.10433550

Lahiri, A.R. (1987) Studies on the odonate fauna of Meghalaya. Records of the Zoological Survey of India, Occasional Paper, 99, 1-402.

Lieftinck, M.A. (1948) Entomological results from the Swedish expedition 1934 to Burma and British India. Odonata. Arkiv For Zoologi, 41A (10), 1-23.

Needham, J.G. (1930) A Manual of the Dragonflies of China. A Monographic Study of the Chinese Odonata. Zoologia Sinica, Series A (Invertebrates of China), XI (Fascicle 1), $345+11$ pp., 20 pls. [The Fan Memorial Institute of Biology, Peiping]

Vick, G.S. (1989) List of the dragonflies recorded from Nepal, with a summary of their altitudinal distribution (Odonata). Opuscula zoologica fluminensia, 43, 1-21.

Watson, J.A.L. \& O'Farrell, A.F. (1991) Odonata (dragonflies and damselflies). In: Naumann, I.D., Carne, P.B., Lawrence, J.F., Nielsen, E.S., Spradbery, J.P., Taylor, R.W., Whitten, M.J. \& Littlejohn, M.J. (Eds.), The insects of Australia. $2^{\text {nd }}$ Edition. Melbourne University Press, Melbourne, pp. 294-310.

Wilson, K.D.P. \& Reels, G.T. (2003) Odonata of Guangxi Zhuang autonomous region, China, Part 1: Zygoptera. Odonatologica, 32, 237-279.

Wilson, K.D.P. \& Xu, Z. (2007) Odonata of Guangdong, Hong Kong and Macau, South China, part 1: Zygoptera. International Journal of Odonatology, 10, 87-128. https://doi.org/10.1080/13887890.2007.9748292

Wilson, K.D.P. (2009) Sinolestes editus. The IUCN Red List of Threatened Species, 2009, e.T167190A6313557. https://doi.org/10.2305/IUCN.UK.2009-2.RLTS.T167190A6313557.en

Yeh, W.-C., Tang, H.-C., Chen, S.-L. \& Tsou, M.-H. (2006) Three dragonflies (Odonata) newly recorded in Taiwan. Formosan Entomology, 26, 187-195.

Zhou, X. \& Zhou W.B. (2008) A new species of the genus Megalestes (Odonata: Chlorolestidae) from China. Entomotaxonomia, 30 (1), 1-3. [in Chinese with English summary] 